\begin{tabular}{ccr} 
FOLIA & $\begin{array}{c}\text { ENTOMOLOGICA } \\
\text { ROVARTANI KÖZLEMÉNYEK }\end{array}$ \\
Volume 76 & 2015 & pp. 223-240 \\
\hline
\end{tabular}

\title{
New records of ichneumon wasps in Hungary, Romania, Serbia and Slovakia with a key to the Western Palaearctic Xylophrurus species (Hymenoptera: Ichneumonidae)
}

\author{
Zoltán VAS \\ Hungarian Natural History Museum, Department of Zoology, \\ H-1088 Budapest, Baross utca 13, Hungary.E-mail: vas@nhmus.hu
}

\begin{abstract}
Nine ichneumon wasp species (including one genus) were found to be new for the Hungarian fauna: Lissonota biguttata Holmgren, 1860, Temeluch a brevipetiolata Kolarov, 1989, Temelucha mohelnensis Šedivý, 1971, Pleolophus brachypterus (Gravenhorst, 1815), Xylophrurus augustus (Dalman, 1823), Coelichneumon biguttorius (Thunberg, 1789), Coelichneumon sinister (Wesmael, 1848), Carria paradoxa Schmiedeknecht, 1924, and Ophion ocellaris Ulbricht, 1926. Temelucha notata Kolarov, 1989 was found to be new for Romania. The first records of Ophion costatus Ratzeburg, 1848 from Slovakia and Serbia are also reported, as well as Ophion minutus Kriechbaumer, 1879, Ophion obscuratus Fabricius, 1798, Ophion ventricosus Gravenhorst, 1829, Cidaphus alarius (Gravenhorst, 1829), and Priopoda apicaria (Geoffroy, 1785) from Serbia. A tentative key to the females of Western Palaearctic Xylophrurus Förster, 1869 species is provided. With 16 figures.
\end{abstract}

Key words - Carria, Cidaphus, Coelichneumon, Lissonota, Ophion, Pleolophus, Priopoda, Temelucha, Banchinae, Cremastinae, Cryptinae, Ctenopelmatinae, Ichneumoninae, Mesochorinae, Metopiinae, Ophioninae, Carpathian Basin

\section{INTRODUCTION}

Ichneumon wasps (Hymenoptera: Ichneumonidae) constitute one of the most diverse families of the animal kingdom with more than 30,000 described species (TownEs 1969, WAHL 1993). However, they represent one of the most scarcely known insect groups even in the European fauna (see e.g. VAs 2013 for the Hungarian overview). Almost all species are solitary parasitoids of various arthropod hosts (WAHL 1993), including several pest insects; hence, they are an exceptionally important group of potential bio-control agents (GODFRAY 1994).

The ongoing identification process of the undetermined ichneumon wasp material in the Hungarian Natural History Museum (HNHM) has revealed further 9 new species records for the Hungarian fauna (including a new genus 
record), 1 new record for the Romanian fauna, 6 for the Serbian fauna, and 1 for the Slovakian fauna. Hereby I report them in alphabetical order (first by subfamilies, then by genera and species).

I also provide a tentative identification key to Xylophrurus Förster, 1869 (Cryptinae) species of the Western Palaearctic region. Although there are only 7 species occurring there, the species-level identification is complicated. No comprehensive key has been published including all the 7 species; each earlier work covered only a subset of them. Additionally, many different generic combinations and later synonymised names were used in previous works (20 specific names are now in combination with Xylophrurus, 7 valid and 13 junior synonyms) (Yu et al. 2012). My attempt here is to present a nomenclaturally updated key including all valid Xylophrurus species of the region.

\section{MATERIAL AND METHODS}

The tentative key to females is based on original descriptions, subsequent treatments and previous keys (SCHMIEDEKNECHT 1904, 1931, HEINRICH 1951, Kasparyan 1981, Horstmann 19936, Schwarz \& Shaw 1998).

Ichneumonidae taxonomy and nomenclature follow YU \& HoRsTMANN (1997) and YU et al. (2012). The identification was based on the keys provided by BAJÁRI (1960), TownEs et al. (1965), TownEs (1969, 1970a, 1970b, 1971), ŠEDIvý (1971), Brock (1982), Horstmann (1993a), Kolarov (1997), SCHWENKE (1999), BROAD (2011a,b), and RIEDEL (2012). The specimens were identified by the author using a Nikon SMZ645 stereoscopic microscope. Earlier records of ichneumon wasp species in the corresponding country's fauna were checked in MocsÁRY (1897), ZilAHI-KIss (1924, 1926, 1929), BAJÁRI (1960), BAJÁRI \& MóczÁr (1969), Šedivý (1989), SCHWEnke (1999), Kolarov (2008), and YU et al. (2012). The voucher specimens are deposited in the HNHM Hymenoptera Collection.

\section{RESULTS}

Banchinae

Lissonota biguttata Holmgren, 1860

(Fig. 1)

Material - Hungary, Veszprém County, Zánka, Bálint-hegy [= hill], 8.VI.2013, leg. T. Németh. - A single female specimen was collected by window trap. 


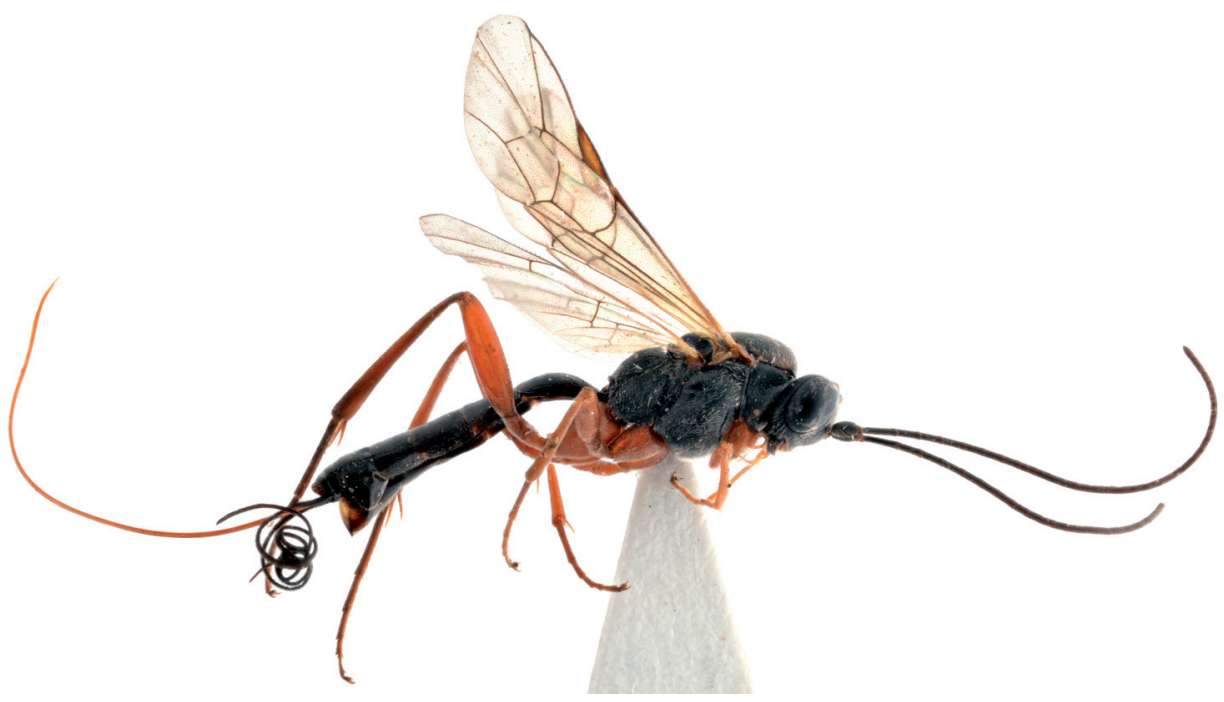

Fig. 1. Lissonota biguttata Holmgren, 1860, female

Remarks - Lissonota biguttata has been found in most European countries (YU et al. 2012). YU et al. (2012) lists this species as present in Hungary citing ZILAHI-KISS (1924); however, the localities in ZILAHI-KISS's (1924) work refer to present-day Romania (Borosjenő [= Ineu], and Mt. Retezat). Hence, the first record for Hungary is the one reported here. Lissonota biguttata is a koinobiont endoparasitoid of the geometrid moths Oreophtera spp. (BETz \& SCHWERDTFEGER 1970).

\section{Cremastinae}

Temelucha brevipetiolata Kolarov, 1989

(Fig. 2)

Material - Hungary, Budapest, XII. district, Svábhegy, 4.V.1900, leg. Gy. Szépligeti. - A single male specimen was collected.

Remarks - Temelucha brevipetiolata has only been recorded from Bulgaria and Turkey so far (Kolarov 1989, Kolarov \& Beyarslan 1999). Kolarov (1997) supposed that this species may be a Balkan endemism; however, the Hungarian occurrence suggests a wider distribution in Europe. This species might be a koinobiont endoparasitoid (WAHL 1993) without any known hosts (Yu et al. 2012). 


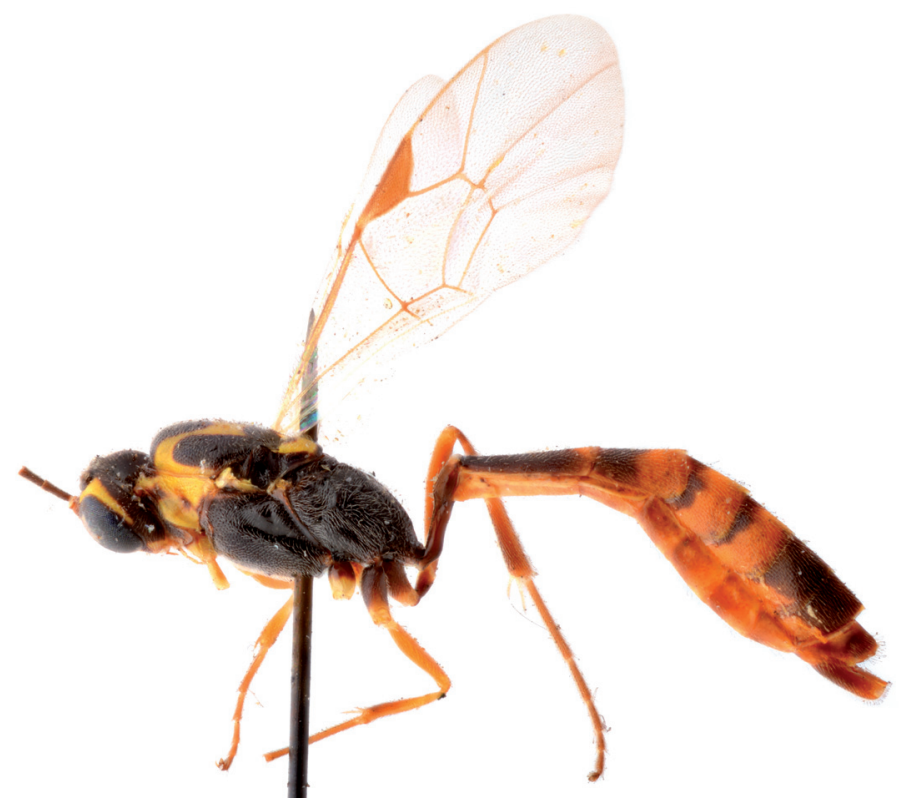

Fig. 2. Temeluch a brevipetiolata Kolarov, 1989, male

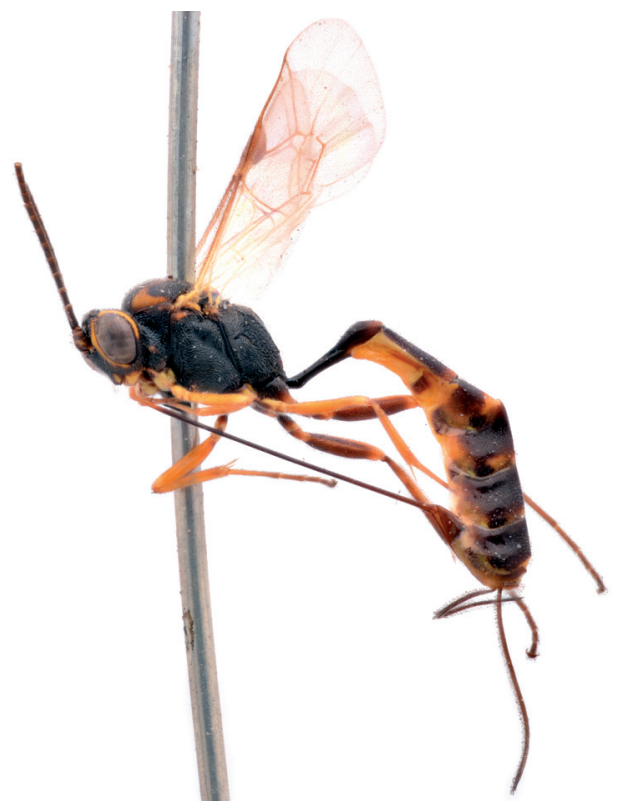

Fig. 3. Temelucha mohelnensis Šedivý, 1971, female 
Temelucha mohelnensis Šedivý, 1971

(Fig. 3)

Material - Hungary, Budapest, XII. district, Svábhegy, 17.VII.1899, leg. Gy. Szépligeti. - A single female specimen was collected.

Remarks - Temelucha mohelnensis has been found in several countries of Western and Central Europe (Yu et al. 2012). This species might be a koinobiont endoparasitoid (WAHL 1993) without any known hosts (YU et al. 2012).

Temelucha notata Kolarov, 1989

(Fig. 4)

Material - Romania, Satu Mare County, Hadad [= Hodod], collecting date unknown, leg. E. Zilahi-Kiss. - A single female specimen was collected.

Remarks - Temelucha notata has been recorded from Bulgaria and Italy (Kolarov 1989, 1995) so far. This species might be a koinobiont endoparasitoid (WAHL 1993) without any known hosts (Yu et al. 2012).

\section{Cryptinae}

Pleolophus brachypterus (Gravenhorst, 1815)

(Fig. 5)

Material - Hungary, Nógrád County, Nagyoroszi, Mt. Börzsöny, 3.VI.2015, leg. V. Szőke. - A single female specimen was collected.

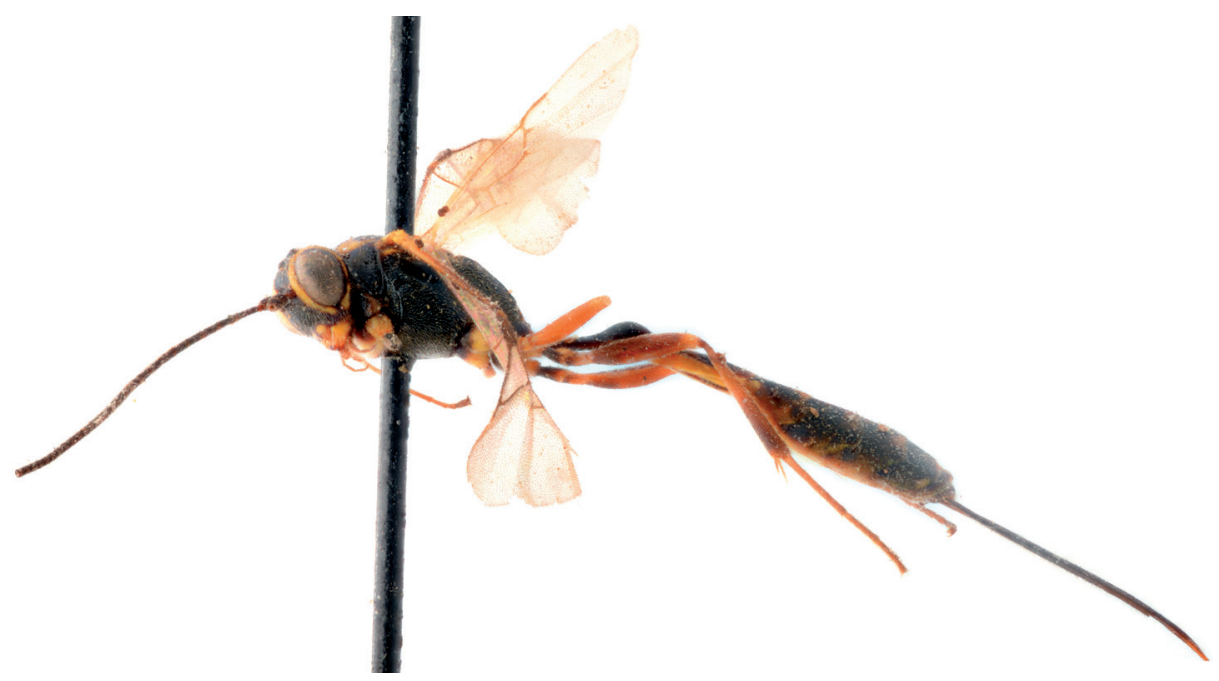

Fig. 4. Temelucha notata Kolarov, 1989, female 
Remarks - Pleolophus brachypterus has been found in most European countries (Yu et al. 2012). Yu et al. (2012) list this species as present in Hungary citing ZILAHI-KISS (1924, 1929); however, the localities in those references refer to present-day Romania (Jeder [= Iadăra], and Mt. Retezat). Hence, the first record for Hungary is the one reported here. The females are brachypterous. This species is a polyphagous ectoparasitoid of cocoons of various insect hosts including Tenthredinidae and Geometridae (Horstmann 1993a).

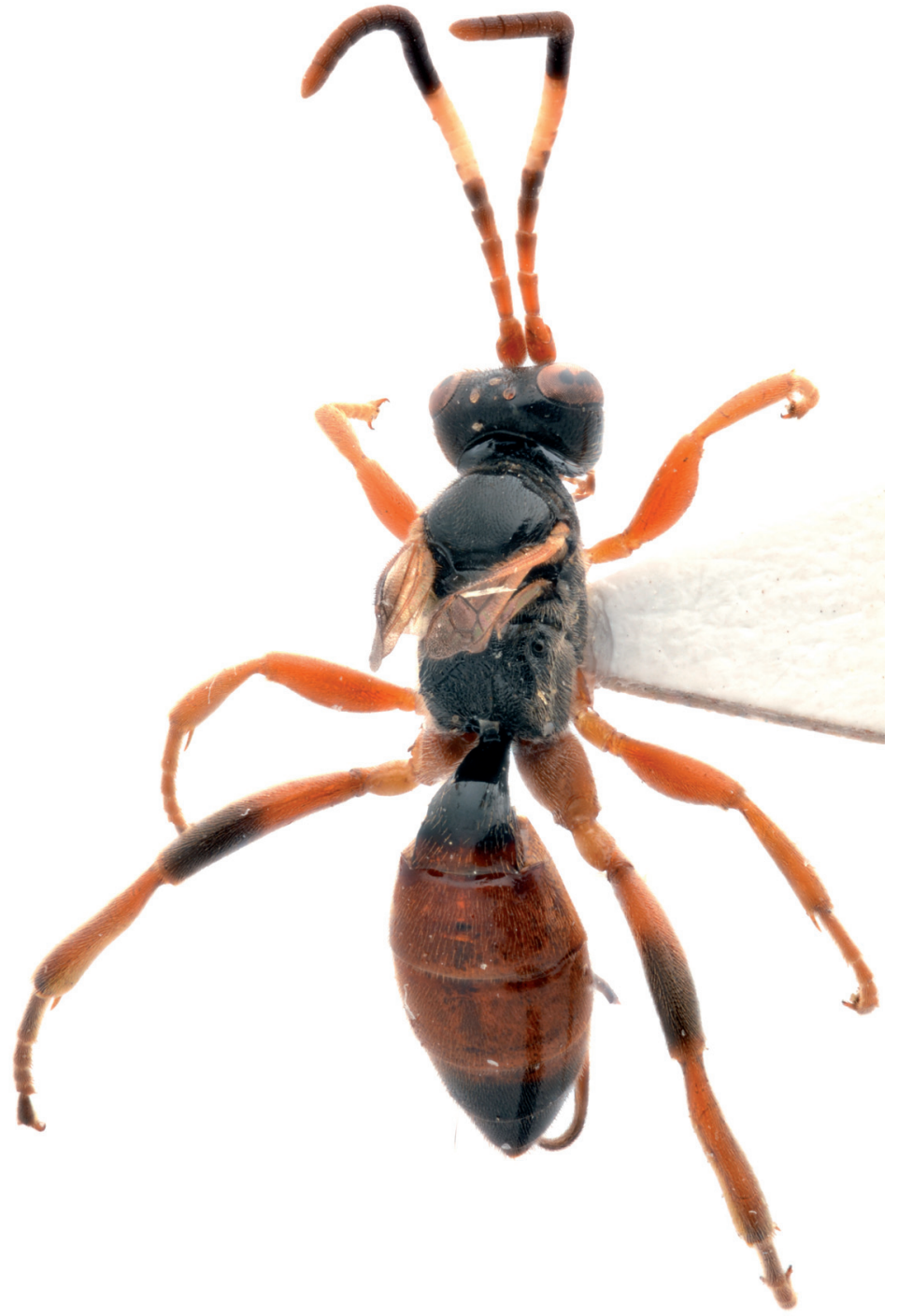

Fig. 5. Pleolophus brachypterus (Gravenhorst, 1815), female 


\section{Xylophrurus augustus (Dalman, 1823)}

(Fig. 6)

Material - Hungary, Pest County, Pilisborosjenő, 24.III.2014, leg. J. Muskovits. - A single female specimen was collected.

Remarks - Xylophrurus augustus is a widespread species in the Western Palaearctic region (YU et al. 2012). Yu et al. (2012) list this species as present in Hungary citing ZILAHI-KIss (1924, 1926); however, the localities in those references refer to present-day Romania (Hadad [= Hodod], Oroszmező [= Rus], Keisd [= Saschiz], and Erdélyi-érchegység [Munții Metaliferi]). Hence, the first record for Hungary is the one reported here. This species is a polyphagous ectoparasitoid of various hosts, including symphytan and aculeatan Hymenoptera and wood boring Coleoptera (see Yu et al. (2012) for a list of references).

A tentative identification key to females of Xylophrurus species occurring in the Western Palaearctic region is provided below.

1 (4) Thorax entirely or on dorsal part red.

2 (3) Antenna with whitish ring

$X$. augustus (Dalman, 1823)

3 (2) Antenna without whitish ring

$X$. nigricornis (Thomson, 1885)

4(1) Thorax black.

5(6) Propodeum with long and acute dentiparal spines

6 (5) Propodeum without dentiparal spines, at most with slightly raised carinae.

7 (8) Ovipositor sheath is subequal to metasoma

$X$. dentatus (Taschenberg, 1865)

8 (7) Ovipositor sheath longer than metasoma.

9 (10) Ovipositor sheath $\sim 2.5 \times$ as long as hind tibia

10 (9) Ovipositor sheath less than $2 \times$ as long as hind tibia.

11 (12) Head unusually wide behind eyes

12 (11) Head not unusually wide behind eyes

X. tumidus (Desvignes, 1856)

X. coraebi (Thomson, 1885)

X. lancifer (Gravenhorst, 1829)

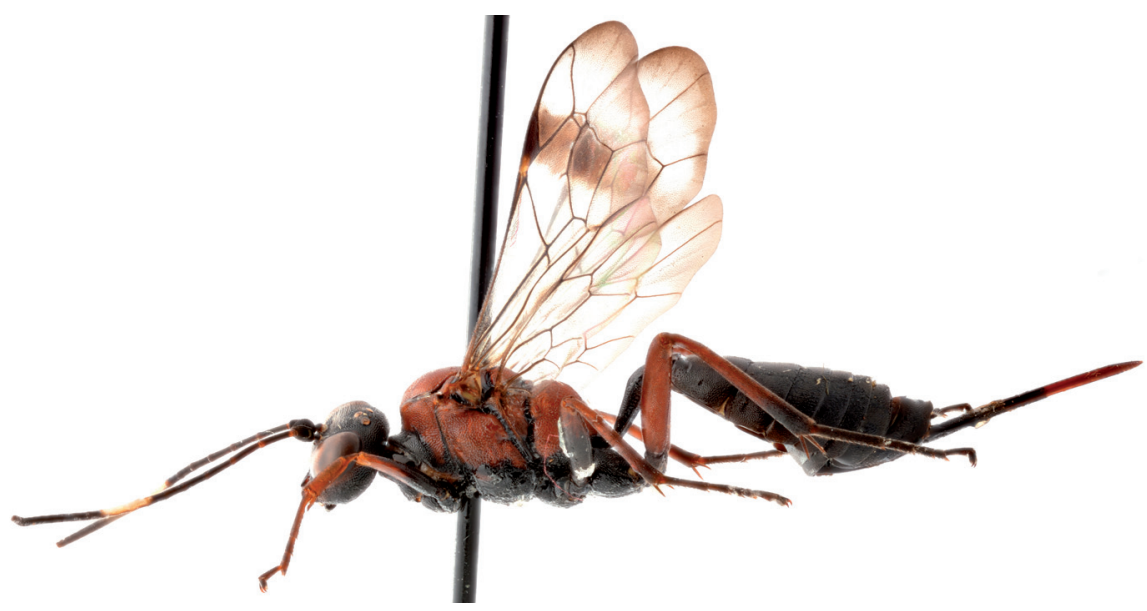

Fig. 6. Xylophrurus augustus (Dalman, 1823), female 


\section{Ctenopelmatinae}

Priopoda apicaria (Geoffroy, 1785)

(Fig. 7)

Material - Serbia, Mt. Kablar, 4354' 44” N, 20¹1' 29” E, 9.V.2015, leg. P. G. Sulyán. - A single male specimen was collected by light trap.

Remarks - Priopoda apicaria is a widespread species in the Western Palaearctic region (YU et al. 2012). This species is a nocturnal endoparasitoid of sawflies (WAHL 1993, Aubert 2000).

\section{Ichneumoninae}

Coelichneumon biguttorius (Thunberg, 1789)

(Fig. 8)

Material - Hungary, Pest County, Göd, 6.VI.2014, leg. I. Lukács. - A single male specimen was collected.

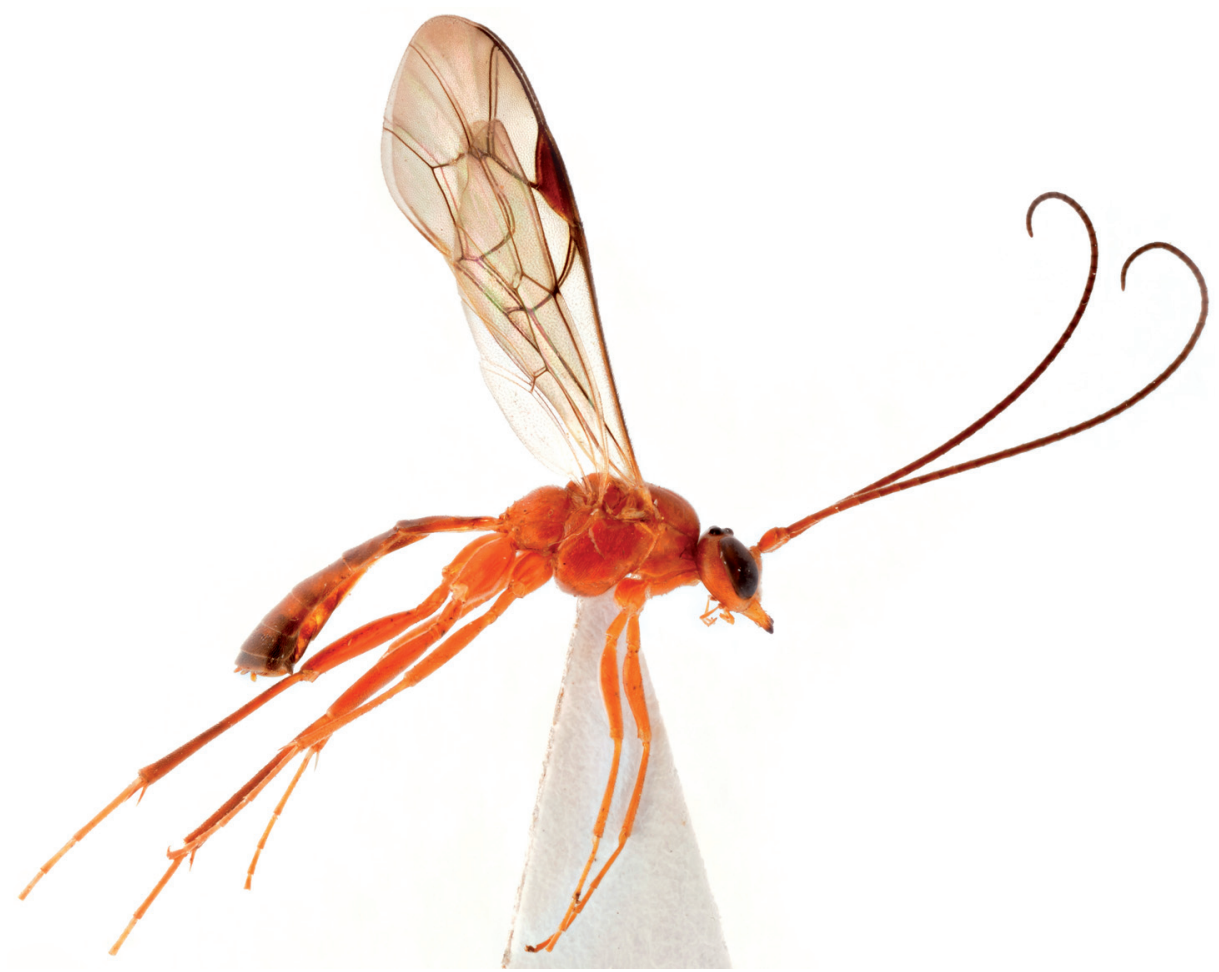

Fig. 7. Priopoda apicaria (Geoffroy, 1785), male 




Fig. 8. Coelichneumon biguttorius (Thunberg, 1789), male

Remarks - Coelichneumon biguttorius seems to be a widespread species in the Palaearctic region; it has been reported from a few countries from Sweden to Mongolia (Yu et al. 2012). This species might be an endoparasitoid of lepidopteran hosts (WAHL 1993); however, no host species has been known yet (YU et al. 2012).

\section{Coelichneumon sinister (Wesmael, 1848)}

(Fig. 9)

Material - Hungary, Pest County, Göd, 18.IX.1987, leg. I. Lukács. - A single female specimen was collected.

Remarks - Coelichneumon sinister has been reported from several countries in the Western and Eastern Palaearctic (Yu et al. 2012). Yu et al. (2012) list this species as present in Hungary citing ZILAHI-KIss (1924, 1929); however, the localities in those references refer to present-day Romania (Hammersdorf 


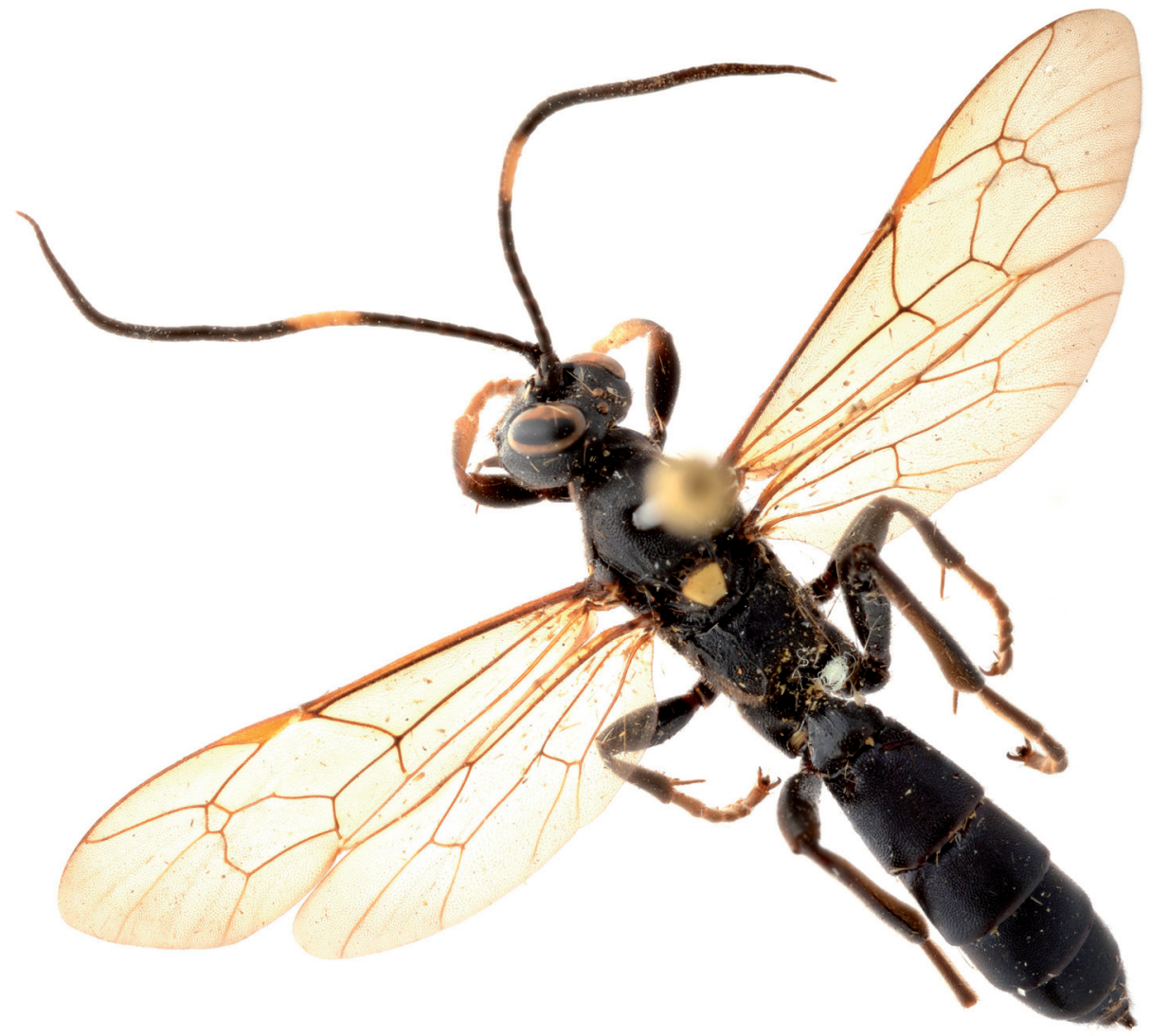

Fig. 9. Coelichneumon sinister (Wesmael, 1848), female

[= Guşterița $]$, Hermannstadt [= Sibiu], and Keisd [= Saschiz]). Hence, the first record for Hungary is the one reported here. This species is an endoparasitoid of various lepidopteran hosts (see YU et al. (2012) for a list of references).

\section{Mesochorinae}

Cidaphus alarius (Gravenhorst, 1829)

(Fig. 10)

Material - Serbia, Ovčar Banja, 435 54’ 33” N, 20 12' 17” E, 8.V.2015, leg. P. G. Sulyán. -2 females were collected by light trap.

Remarks - Cidaphus alarius is a widespread species in the Palaearctic region (Yu et al. 2012). This species is a nocturnal hyperparasitoid of Ichneumonidae and Tachinidae (WAHL 1993, SCHWENKe 1999). 


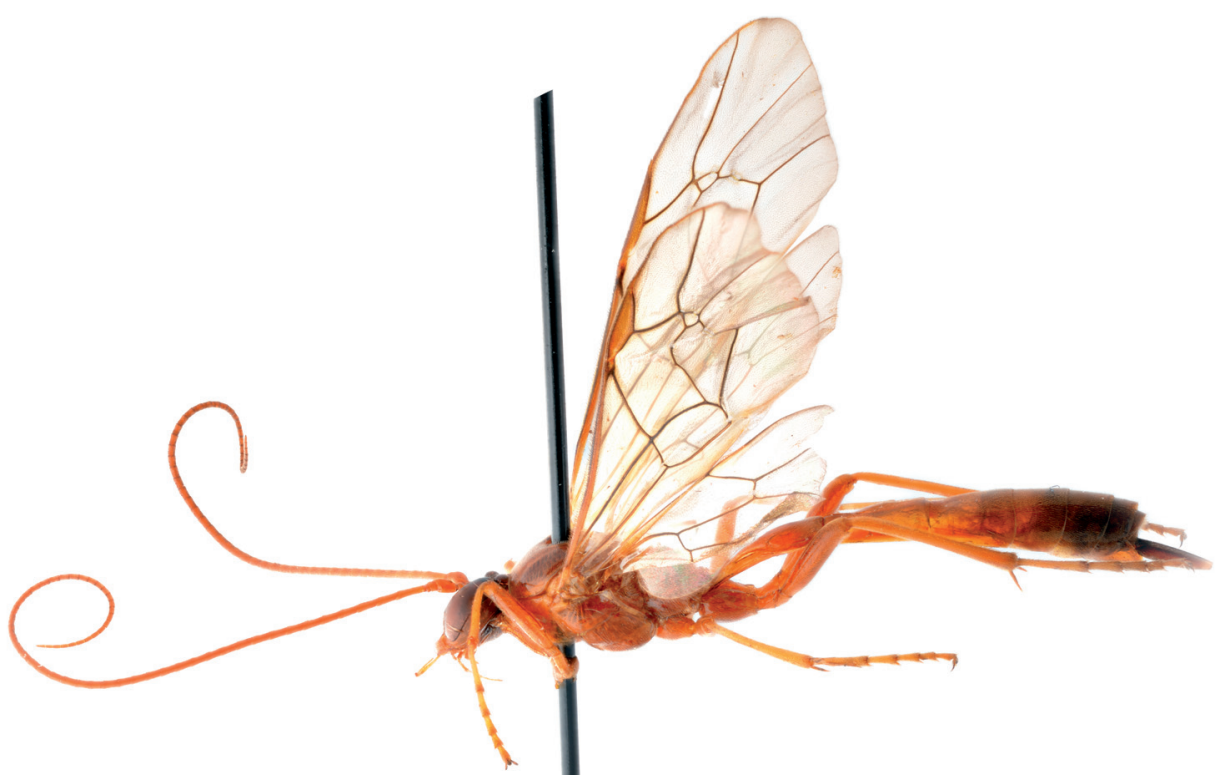

Fig. 10. Cidaphus alarius (Gravenhorst, 1829), female

\section{Metopiinae}

Carria paradoxa Schmiedeknecht, 1924

(Fig. 11)

Material - Hungary, Pest County, Vác, Naszály, 14.IV.2007, leg. O. Merkl, A. Kotán, N. Rahmé. - A single male specimen was collected at sunset with the use of a net attached to the roof of a car.

Remarks - Carria paradoxa seems to be a rare Palaearctic species, it has been reported from only a few countries in the region (YU et al. 2012). It is also the first occurrence of the metopiine genus Carria Schmiedeknecht, 1924 in Hungary. This species is a koinobiont endoparasitoid of tortricid hosts (WAHL 1993, YU et al. 2012).

\section{Ophioninae}

Ophion costatus Ratzeburg, 1848

(Fig. 12)

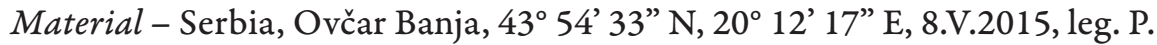
G. Sulyán. - 3 females and 1 male were collected by light trap. - Slovakia, Košice 


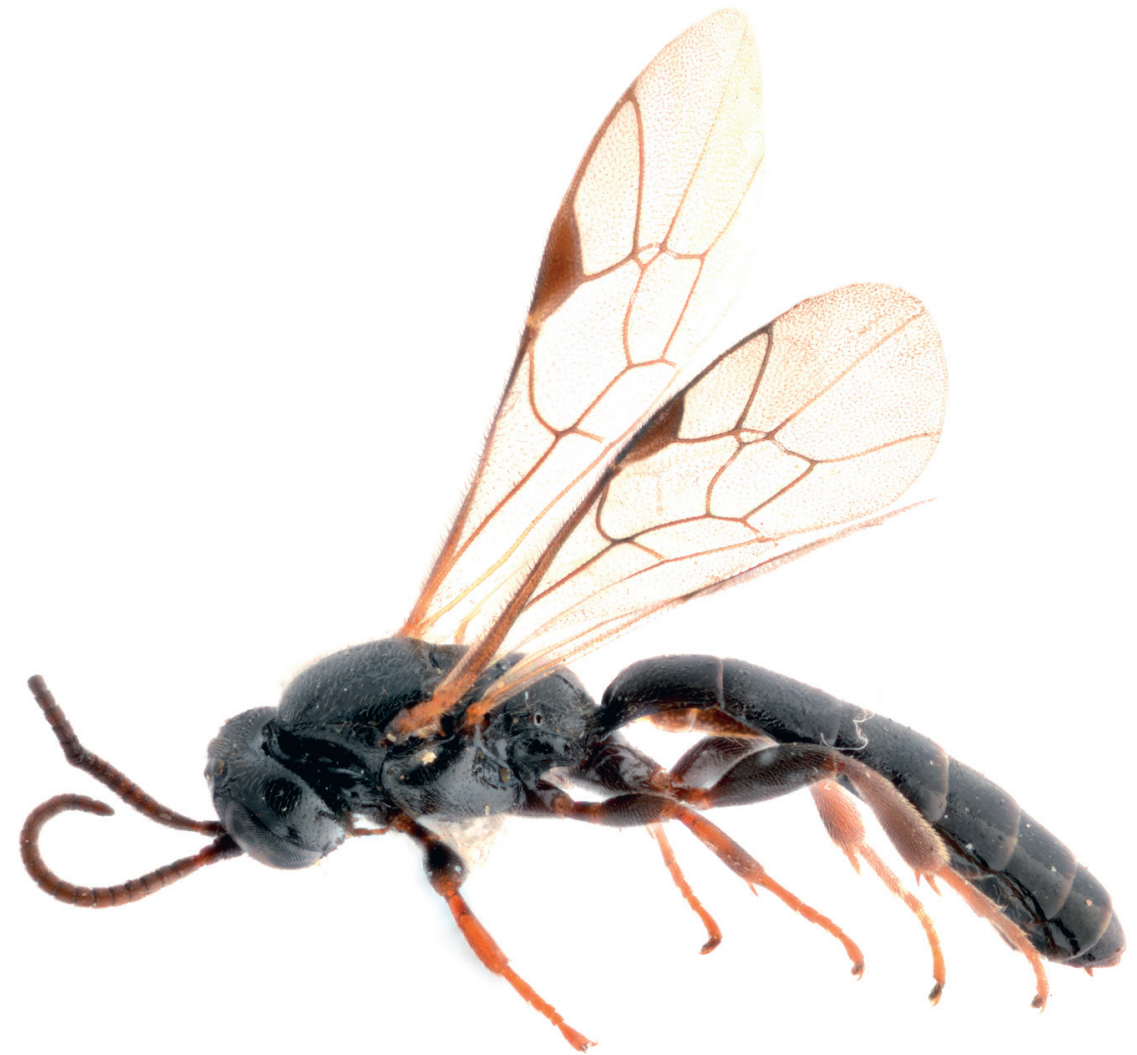

Fig. 11. Carria paradoxa Schmiedeknecht, 1924, male



Fig. 12. Ophion costatus Ratzeburg, 1848, female 
Region, Ardovo, $48^{\circ} 31^{\prime} 16^{\prime \prime} \mathrm{N}, 20^{\circ} 25^{\prime} 22^{\prime}$ E, 17.IV.2015, leg. G. P. Katona, T. Korompai, R. Enyedi. - One male was collected by light trap.

Remarks - Ophion costatus is a widespread species in the Palaearctic region (Yu et al. 2012). ŠEDIVÝ (1989) listed it from Czechoslovakia; however, this record refers to present-day Czech Republic, not to Slovakia. Hence, the two records reported here constitute the first records for Slovakia and for Serbia. This species is a nocturnal koinobiont endoparasitoid of noctuid hosts (WAHL 1993, ŠEDIVÝ 2001, YU et al. 2012).

\section{Ophion minutus Kriechbaumer, 1879}

(Fig. 13)

Material - Serbia, Ovčar Banja, 43 54’ 33” N, $20^{\circ} 12^{\prime} 17^{\prime \prime}$ E, 8.V.2015; Serbia, Mt. Kablar, 43 54' 44” N, 20 11' 29”E, 9.V.2015, leg. P. G. Sulyán. - 6 females and 8 males were collected by light trap.

Remarks - Ophion minutus is a widespread species in the Palaearctic region (Yu et al. 2012). This species is a nocturnal koinobiont endoparasitoid of lepidopteran hosts (WAHL 1993, ŠEDIVÝ 2001, YU et al. 2012).

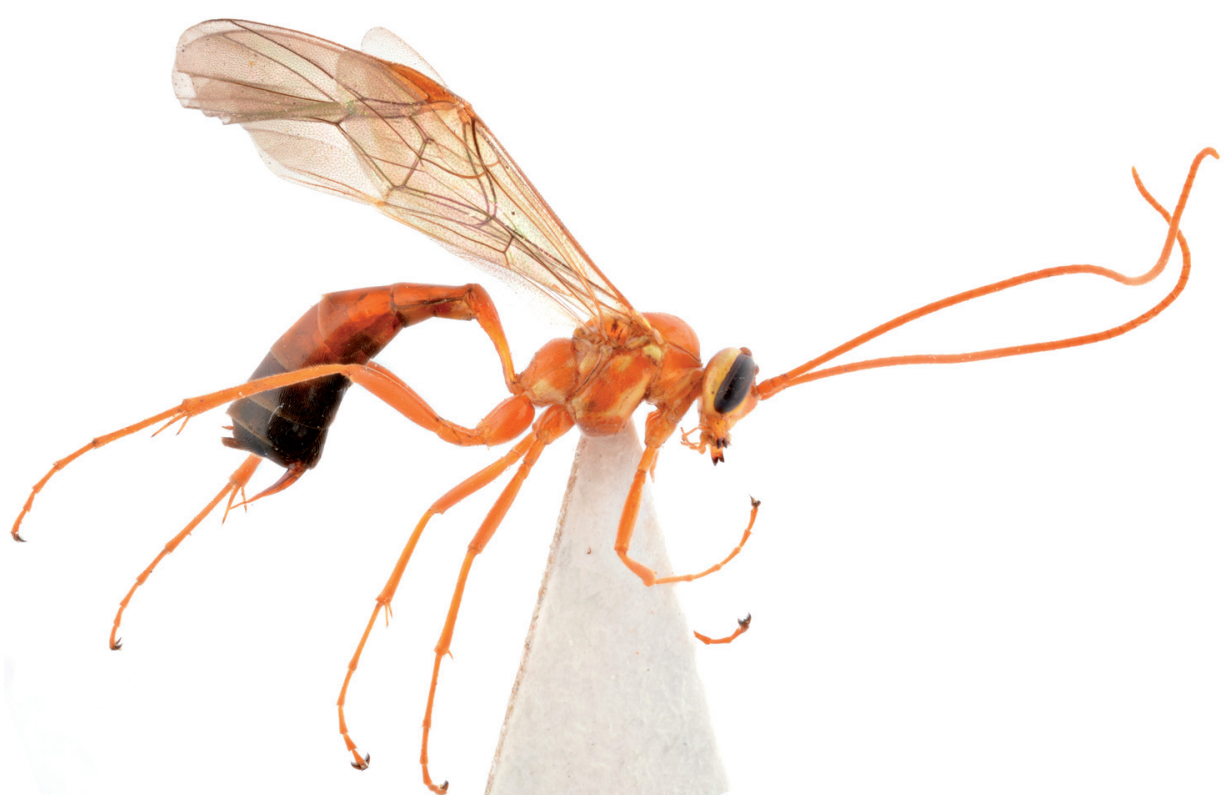

Fig. 13. Ophion minutus Kriechbaumer, 1879, female 
Ophion obscuratus Fabricius, 1798

(Fig. 14)

Material - Serbia, Ovčar Banja, 43 54’ 33” N, 20¹2' 17” E, 8.V.2015; Serbia, Mt. Kablar, $43^{\circ} 54^{\prime} 44^{\prime \prime}$ N, $20^{\circ} 11^{\prime} 29^{\prime \prime}$ E, 9.V.2015., leg. P. G. Sulyán. - 2 females were collected by light trap.

Remarks - Ophion obscuratus is a widespread species in the Palaearctic and Oriental regions (YU et al. 2012). This species is a nocturnal koinobiont endoparasitoid of various lepidopteran hosts (GYőRFI 1943, BROCK 1982, WAHL 1993, YU et al. 2012).

Ophion ocellaris Ulbricht, 1926

(Fig. 15)

Material - Hungary, Pest County, Ócsa, bird ringing station, 10.VI.2015, leg. Á. Mészáros. - A single female was collected by light trap.

Remarks - Ophion ocellaris is a rare but widespread species in Europe (YU et al. 2012). This species is a nocturnal koinobiont endoparasitoid of Thyatiridae and Geometridae hosts (WAHL 1993, ŠEDIVÝ 2001, Yu et al. 2012).

\section{Ophion ventricosus Gravenhorst, 1829}

(Fig. 16)

Material - Serbia, Ovčar Banja, 435 54' 33” N, 20¹2’ 17” E, 8.V.2015, leg. P. G. Sulyán. -6 females were collected by light trap.

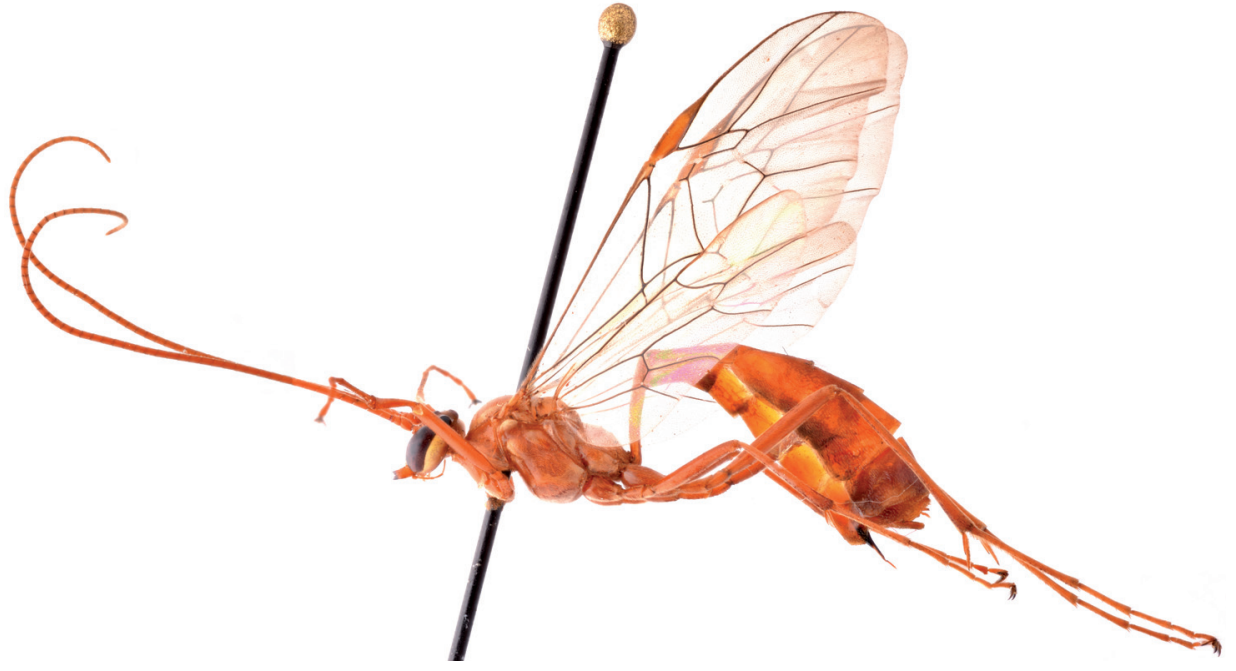

Fig. 14. Ophion obscuratus Fabricius, 1798, female 


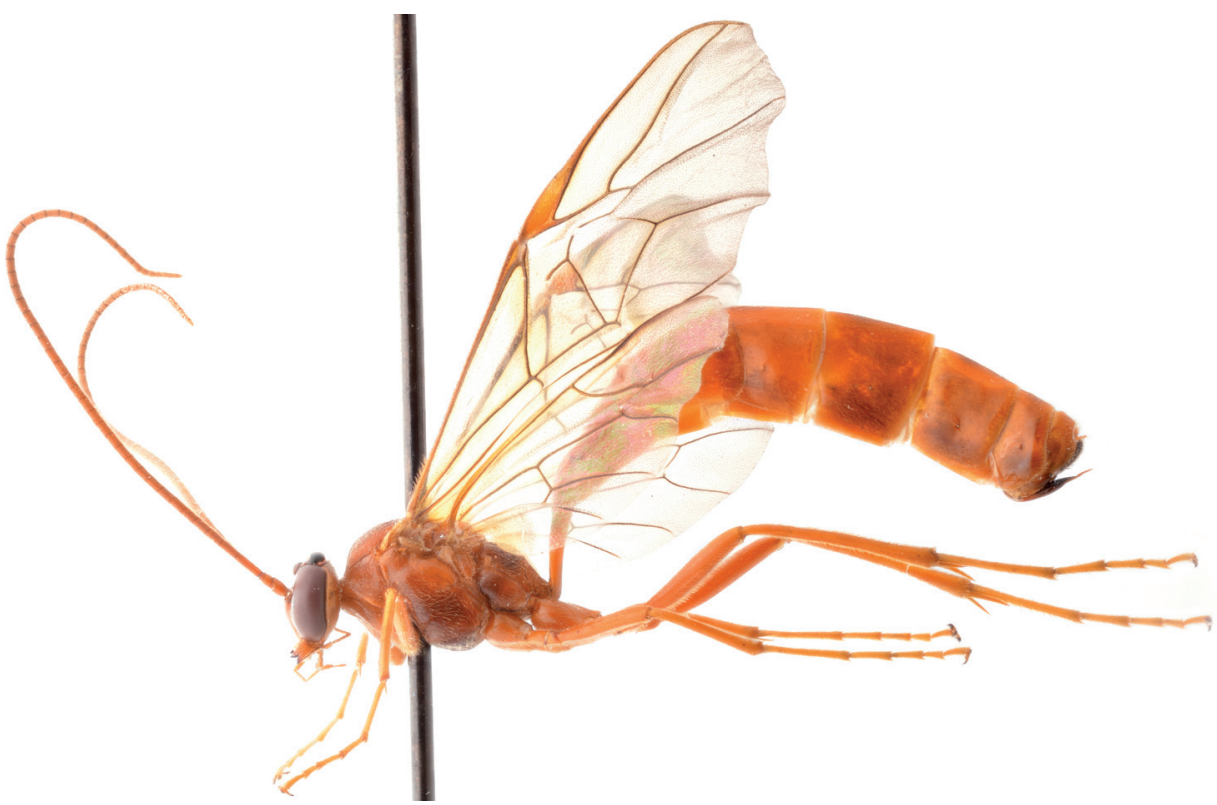

Fig. 15. Ophion ocellaris Ulbricht, 1926, female

Remarks - Ophion ventricosus is a widespread species in the Western Palaearctic region (YU et al. 2012). This species is a nocturnal koinobiont endoparasitoid of various lepidopteran hosts (BROCK 1982, WAHL 1993, YU et al. 2012).

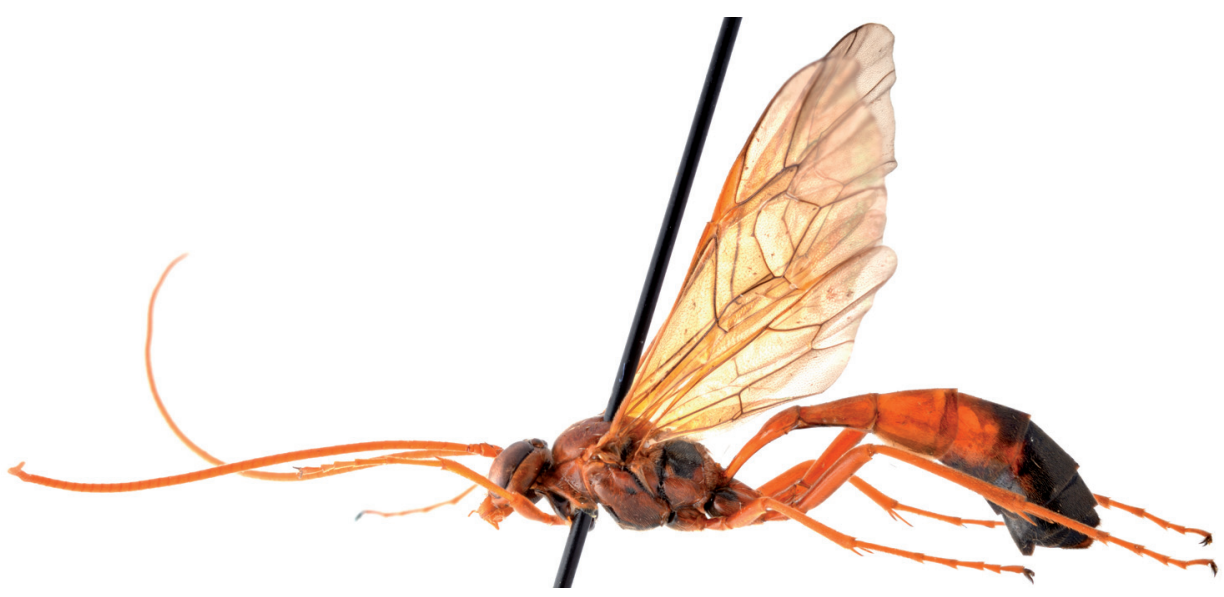

Fig. 16. Ophion ventricosus Gravenhorst, 1829, female 
Acknowledgements - The author, on behalf of HNHM, thanks the people who collected and/ or donated these specimens, namely (in alphabetical order): Róbert Enyedi, Gergely P. Katona, Tamás Korompai, Attila Kotán, István Lukács, Ottó Merkl, Ádám Mészáros, József Muskovits, Tamás Németh, Nikola Rahmé, Péter G. Sulyán, Viktória Szőke. I would like to express my gratitude to Gavin R. Broad (Natural History Museum, London) for checking the characteristics of the Xylophrurus tumidus type specimen. I am grateful to Ottó Merkl for his valuable comments on the manuscript and to Tamás Németh for the high quality photos.

\section{REFERENCES}

AUbert J. F. 2000: Les Ichneumonides ouest-paléarctiques et leurs hôtes. 3. Scolobatinae (= Ctenopelmatinae) et suppl. aux volumes précédents. - Litterae zoologicae: actes du Musée cantonal de zoologie, Lausanne 5: 1-310.

BAJÁri E. \& MóczÁr L. 1969: Fürkészdarázs-alkatúak IV. Ichneumonoidea IV. - In: SZÉKESSY V. (ed.): Magyarország Állatvilága. Fauna Hungariae, XI, 7. Akadémiai Kiadó, Budapest, $122 \mathrm{pp}$.

BAJÁRI E. 1960: Fürkészdarázs-alkatúak I. Ichneumonoidea I. - In: SzÉKessy V. (ed.): Magyarország Állatvilága. Fauna Hungariae, XI, 4. Akadémiai Kiadó, Budapest, 266 pp.

Betz E. \& SChwerdtFeger F. 1970: Lepidopteren-Parasiten aus zwei nordwestdeutschen Eichenwäldern. - Entomophaga 15: 347-351.

BROAD G. R. 2011a: Identification key to the subfamilies of Ichneumonidae (Hymenoptera). - Natural History Museum, London. Online: http://www.nhm.ac.uk/resources-rx/files/ich_subfamily_key_2_11_compressed-95113.pdf [Accessed 30 September 2015.]

BroAD G. R. 2011b: Keys for the identification of British and Irish nocturnal Ichneumonidae. Natural History Museum, London. Online: http://www.nhm.ac.uk/resources-rx/files/keysfor-nocturnal-workshop-reduced-109651.pdf [Accessed 30 September 2015.]

BROCKJ.P. 1982: A systematic study of the genus Ophion in Britain (Hymenoptera, Ichneumonidae). - Tijdschrift voor Entomologie 125(4): 57-97. Online: http://biostor.org/reference/49906 [Accessed 30 September 2015.]

Godfray H. C. J. 1994: Parasitoids. Behavioral and Evolutionary Ecology. - Princeton University Press, Princeton, 473 pp.

GYöRFI J. 1943: Beiträge zur Kenntnis der Wirte von Schlupfwespen. - Zeitschrift für Angewandte Entomologie 30: 79-103.

HeinRICH G. H. 1951: Ichneumoniden der Steiermark (Hym.). - Bonner Zoologische Beiträge 2: 235-290. Online: http://zoologicalbulletin.de/BzB_Volumes/Volume_02_3_4/235_290_ BZB02_3_4_Heinrich_Gerd.PDF [Accessed 30 September 2015.]

Horstmann K. 1993a: Revision der brachypteren Weibchen der westpaläarktischen Cryptinae (Hymenoptera, Ichneumonidae). - Entomofauna 14(7): 85-148.

Horstmann K. 1993b: Revision der von Ferdinand Rudow beschriebenen Ichneumonidae I. (Hymenoptera). - Beiträge zur Entomologie 43: 3-38.

Kasparyan D. 1981: Tom III. Pereponchatokryl'e. Tretya chast'. - In: Medvedev G. S. (ed.) Opredelitel' nasekomykh evropeyskoy chasti SSSR. Nauka, Leningrad, 688 pp.

Kolarov J. A. \& Beyarslan A. 1999: Beitrag zur Kenntnis der Turkischen Ichneumoniden 4. Cremastinae (Hymenoptera, Ichneumonidae). - Entomofauna 20(1): 1-8.

Kolarov J. A. 1989: Taxonomic and faunistic study on Bulgarian Cremastinae (II) (Insecta, Hymenoptera, Apocrita: Ichneumonidae). - Faunistische Abhandlungen 16: 149-154. 
Kolarov J. A. 1995: Cremastinae (Hymenoptera, Ichneumonidae) from Italy and some adjacent regions. - Linzer Biologische Beiträge 27(2): 1103-1114. Online: http://www.landesmuseum. at/pdf_frei_remote/LBB_0027_2_1103-1114.pdf[Accessed 30 September 2015.]

Kolarov J. A. 1997: A review of the Cremastinae of the Balkan Peninsula, Turkey and Cyprus with zoogeographical notes (Hymenoptera: Ichneumonidae). - Beiträge zur Entomologie 47(1): 169-199.

Kolarov J. A. 2008: A catalogue of the (former) Yugoslavian Ichneumonidae (Hymenoptera, Insecta). - Linzer Biologische Beiträge 40(2): 1585-1739. Online: http://www.zobodat.at/stable/ pdf/LBB_0040_2_1585-1739.pdf [Accessed 30 September 2015.]

MocsÁry S. 1897: Ordo Hymenoptera. - In: A Magyar Birodalom Állatvilága. Fauna Regni Hungariae. Magyar Királyi Természettudományi Társulat, 113 pp.

Riedel M. 2012: Revision der westpaläarktischen Arten der Gattung Coelichneumon Thomson (Hymenoptera: Ichneumonidae: Ichneumoninae). - Linzer Biologische Beiträge 44(2): 14771611. Online: http://www.landesmuseum.at/pdf_frei_remote/LBB_0044_2_1477-1611.pdf [Accessed 30 September 2015.]

SChmiede KNecht O. 1904: Opuscula Ichneumonologica. II. Band. Fasc. VI-VII. Cryptinae. - Private edition, Blankenburg in Thüringen, pp. 411-562. Online: http://www.biodiversitylibrary. org/item/91328\#page/7/mode/1up [Accessed 30 September 2015.]

Schmiedeknecht O. 1931: Opuscula Ichneumonologica. Supplement-Band. Neubearbeitungen. Fasc. XI. - Private edition, Blankenburg in Thüringen, pp. 1-45.

Schwarz M. \& SH Aw M. R. 1998: Western Palaearctic Cryptinae (Hymenoptera: Ichneumonidae) in the National Museums of Scotland, with nomenclatural changes, taxonomic notes, rearing records and special reference to the British check list. Part 1. Tribe Cryptini. - Entomologist's Gazette 49: 101-127. Online: http://citeseerx.ist.psu.edu/viewdoc/download?doi=10.1.1.4 67.3318\&rep=rep1\&type $=$ pdf [Accessed 30 September 2015.]

SCHWENKE W. 1999: Revision der europäischen Mesochorinae (Hymenoptera, Ichneumonoidea, Ichneumonidae). - Spixiana Supplement 26: 1-124. Online: http://www.biodiversitylibrary. org/page/29541279\#page/385/mode/1up [Accessed 30 September 2015.]

ŠEDIVÝ J. 1971: Revision der europäischen Temelucha-Arten (Hym., Ichneumonidae). - Acta scientiarum naturalium Academiae scientiarum bohemoslovacae, Brno 5(1): 1-34 pp.

ŠEDIVÝ J. 1989: Enumeratio Insectorum Bohemoslovakiae. Check list of Czechoslovak insects III (Hymenoptera). - Acta Faunistica Entomologica Musei Nationalis Pragae 19: 1-194.

ŠEDIVÝ J. 2001: Contribution to the taxonomy and knowledge of hosts of ichneumonids (Hymenoptera: Ichneumonidae). - Klapalekiana 37(1-2): 59-69.

Townes H. 1969: The genera of Ichneumonidae. Part 1. - Memoirs of the American Entomological Institute 11: 1-300.

Townes H. 1970a: The genera of Ichneumonidae. Part 2. - Memoirs of the American Entomological Institute 12: 1-537.

Townes H. 1970b: The genera of Ichneumonidae. Part 3. - Memoirs of the American Entomological Institute 13: 1-307.

Townes H. 1971: The genera of Ichneumonidae. Part 4. - Memoirs of the American Entomological Institute 17: 1-372.

Townes H., Momoi S. \& Townes M. 1965: A catalogue and reclassification of Eastern Palearctic Ichneumonidae. - Memoirs of the American Entomological Institute 5: 1-661.

VAS Z. 2013: First records of three ichneumon wasp species in Hungary (Hymenoptera: Ichneumonidae). - Folia entomologica hungarica 74: 189-194. Online: http://publication.nhmus.hu/ folent/cikkreszletes.php?idhoz=4817 [Accessed 30 September 2015.]

Wahl D. B. 1993: Family Ichneumonidae. - In: Goulet H. \& Huber J. T. (eds): Hymenoptera of the World: An identification guide to families. Agriculture Canada, Ottawa, pp. 395-509. 
Yu D. S. \& Horstmann, K. 1997: A catalogue of world Ichneumonidae (Hymenoptera). - The American Entomological Institute, Gainesville, 1558 pp.

Yu D. S., van Achterberg C. \& Horstmann K. 2012: Taxapad 2012, Ichneumonoidea 2011. Database on flash-drive. www.taxapad.com, Ottawa, Ontario, Canada.

ZiLAHI-Kiss E. 1924: Beitrag zur Kenntnis der ungarischen und siebenbürgischen Ichneumoniden(Schlupfwespen-) Fauna. - Verhandlungen und Mitteilungen des Siebenbürgischen Vereins für Naturwissenschaften in Hermannstadt 72-74: 32-146.

ZILAHI-KIss E. 1926: Zweiter Beitrag zur Kenntnis der ungarischen und siebenbürgischen Ichneumoniden- (Schlupfwespen-) Fauna. - Verhandlungen und Mitteilungen des Siebenbürgischen Vereins für Naturwissenschaften in Hermannstadt 75-76: 74-120.

ZiLAHI-KIss E. 1929: Dritter Beitrag zur Kenntnis der ungarischen und siebenbürgischen Ichneumoniden- (Schlupfwespen-) Fauna. - Verhandlungen und Mitteilungen des Siebenbürgischen Vereinsfür Naturwissenschaften in Hermannstadt 79-80: 89-144. Online: http://www.landesmuseum.at/pdf_frei_remote/VerhMittNaturwissHermannstadt_79-80_1_0089-0144.pdf [Accessed 30 September 2015.] 